\title{
Understanding Traditional Meat Processing Knowledge among the Borana Pastoralist of Northern Kenya
}

\author{
Buke Galma Dabasso ${ }^{1}$, Hassan Guyo Roba ${ }^{2}$, Anselimo Makokha ${ }^{1}$, Arnold Onyango ${ }^{1} \&$ Julius Maina $^{1}$ \\ ${ }^{1}$ Jomo Kenyatta university of Agriculture and Technology, Kenya \\ ${ }^{2}$ National Museum of Kenya, Kenya \\ Correspondence: Buke Galma Dabasso, Jomo Kenyatta university of Agriculture and Technology, Kenya. Tel: \\ 254-710-482-642. E-mail: buke.galma@gmail.com
}

\author{
Received: April 18, $2018 \quad$ Accepted: May 6, $2018 \quad$ Online Published: May 22, 2018 \\ doi:10.5539/jfr.v7n4p30 URL: https://doi.org/10.5539/jfr.v7n4p30
}

\begin{abstract}
Indigenous knowledge on food preparation is an activity practised in almost all agricultural production system. Amongst the Borana pastoralist of Northern Kenya, milk and meat production are the cornerstone of livelihood, and more often abundance occurs without possibility of immediate consumption, triggering the need to preserve surplus for future consumption. The objective of this paper is to document and understand traditional meat preparation knowledge amongst Borana pastoralist's women of Northern Kenya.

The method of collecting information included in-depth interviews and participant observations to document meat preparation skills and knowledge of Borana people as appertains to traditional food ways. It was observed that methods of traditional meat processing and preparation included different forms of drying, use of heat and storage in fat. Fourteen traditional meat products and seven preservation techniques were documented. Drying and deep frying were the major form of meat preservation. Women skillfully put a lot of effort in all stages of meat preparation to produce an end product that is not only shelf stable but traditional products that are appreciated and nutritious. It was observed that only four of the products are currently in use, an indication of steady decline in meat handling knowledge and preparation.
\end{abstract}

Keywords: food knowledge, cooking, food skills, meat, processing, preservation, tradition Borana

\section{Introduction}

Traditional food processing and preservation is a universal phenomenon that has been practised for centuries by different communities around the world, manifesting in different ways and in different localities. In Asia, America and Europe, local food preservation techniques have been practised either to increase shelf life of food, to reduce spoilage or to enhance flavor or taste (Bessiere, 1998; Bora, 2014; Guyot, 2006; Nam, 2010; Rai, 2009)

In Africa in general and Kenya in particular there are many traditionally processed food products. For instance Suya (tsire or balangu),banda (kundi) and kilishi are the most important traditionally processed meats in Nigeria and other West African countries (FNIFS,T2008). In Kenya, Chikati (2014) pointed out that food like meat could be dried in the sun and or on fire and then stored in the pot for as long as it was needed without rotting. Meat and fish were preserved by cutting into thin strips and drying by fire (Khusika). Oniango (2004) described that Somali, dried meat (otkac or nyirnyir) is prepared from camel meat (hilib gel) where strips of sun-dried meat are cut into small pieces that are fried (usually in oil with garlic and (iliki) and immersed in camel ghee (subag). This is an indication that traditional food processing is an activity which has been practised in time and place.

Borana Pastoralists have profound knowledge of their livestock and their environment. Through daily intricate activities of managing livestock and livestock products they have acquired the knowledge over a long period of time. According to Argawal, (1993) knowledge is generated in the immediate context of the livelihoods of people, where he posited that it is a dynamic entity that undergoes constant modifications as the needs of the communities' change. The traditional meat processing knowledge maintained by Borana pastoralists is tacit in nature and thus only known to talented individuals. In this case, the knowledge is held by women as demonstrated in the foregoing, as they prepare and process the traditional meat. According to Nonaka (2006) tacit knowledge is highly personal and hard to formalize as it is deeply rooted in actions and routines unlike 
explicit knowledge which is formal and systematic. Among the Borana, the daily activities of tending to livestock and domestic chores entails processes of socialization and networking. While men mostly perform outdoor activities of herding livestock, women usually take charge of domestic chores of milking cows, cleaning and preparation of food. Furthermore, these activities create a lot of interactions among the members of the communities creating atmosphere of actions where passing and learning of knowledge and skills happen naturally. As suggested by Fonte (2008) tacit knowledge is created through normal processes of socialization as a form of knowledge transmitted in a community through its social norms and habits.

Cajete (2000) opined that local knowledge was made understandable through demonstration and observation accompanied by thoughtful stories in which the lessons were embedded. Boranas' local meat processing knowledge is rooted in the skills of women practitioners and the storage tools they use. Women milk cows using containers made from hide and stored in gourds or wooden containers. Meat products are preserved in dhibe and dhool made from hides and carved from wood. Roth (2001) pointed out that all artifacts are products of complex transaction and communication processes and that a lot of cultural knowledge and experience is "built" into them.

Traditional meat products are carefully prepared following the traditions, procedures and practices. Women paid careful attention to both taste, aroma and skillfully handled the products for appreciation by the family and communities. Women communicate through their cooking, asserting their place in the family and community, and shaping the actions and behaviors of others (Vallianatos, 2008). These experts/skilled Borana women who possess the traditional meat processing knowledge are acknowledged and are identified in the villages. In their rural abode their skills and products are sought after beyond village borders elevating traditional meat product to a prestigious position in the community. Feagan (2007) suggested that traits and characters of place and the skills of the producers and traditions of cuisine in specific places are perceived in such designation as containing more meaningful and comprehensive information about food status. It is this tacit knowledge and skills that Borana women have, which led to various processing and preservation of traditional meat products among the Borana communities.

However, like in many other rural societies the traditional knowledge in handling, processing and preserving foods are under threat from modernization where traditional practices have been forgone for supposedly better modern processing approaches of foods. The local knowledge of meat processing is thus declining, while the younger generations are not enthusiastic in learning the knowledge leaving this tacit knowledge to dwindle and remain restricted mainly amongst elderly women today. Ohmagari (1997) argued that social changes caused by modernization like schooling, and the introduction of television have induced value changes among the younger generation.

Therefore, documentation of valuable meat traditional knowledge is necessary so as to explore opportunity for reviving the knowledge and possibly promote the traditional products for income generation through value addition.

This is articulated by Bessière (1998) that promoting a specific gastronomic product by conserving skills and techniques leads to re-enacting history, re-appropriating what has been lost and also helping to create, innovate and accept change.

Moreover, since Borana traditional meat knowledge is tacit in nature, documentation of these knowledge and understanding, needs methods which can give not only historical experiences but practical aspect of processing. Hence various methods were applied to collect data and gather information. Thus, the objective of this paper was to document traditional meat preparation knowledge of Borana pastoralist's women of Northern Kenya focusing on the aspects of knowledge, processes, products as well as preservation techniques.

\section{Materials and Methods}

\subsection{Background Information}

Borana speaking groups are the predominant group in the county and they dominate the area stretching from southern Ethiopia and vast part of Northern Kenya.

Borana and majority of neighboring pastoralists still rely on pastoral production and practices mobility to access pasture and water resources. The prevailing livelihood option is pastoralism where cattle, sheep, goats and camels are kept in communal grazing lands. Livestock form key individual or family assets for food and income, and also for defining social and cultural identity. (Dabasso, 2014)

Livestock herding is commonly practised among Borana, Gabra and Rendille groups which generally fall in two categories. One is home-based herding, which involves the herding and milking cattle with calves and small 
stock close to the encampments and the other is satellite or fora herding in far flung open grazing rangelands (Liao, 2014). They keep cattle, small stock and to some extent camel.

While in the past the Borana used to depend on livestock and livestock products, the source of livelihood has changed currently. People now consume crop products such as cereals, pulses and vegetable oil. These are purchased from shops or donated by Non-Governmental Organizations who provide relief services or food assistance program especially during drought - a period of prolonged absence of good rains. This less dependence on livestock and livestock products do have consequences on the knowledge of food preparation methods and processing techniques.

\subsection{Study Area and Population}

Marsabit County has four sub-counties, and this study focused on Moyale and Saku sub-county as depicted in Fig.1. In these sub-counties Borana speaking people are majority. In terms of population density, Moyale constituency has 103,799 while Saku has 46, 502 according to KNBS (2009) population census. The area experiences temperatures ranging from a minimum of $10^{\circ} \mathrm{C}$ to a maximum of $30^{\circ} \mathrm{C}$, with an annual average of $20^{\circ} \mathrm{C}$. Rainfall ranges between $200 \mathrm{~mm}$ to $1000 \mathrm{~mm}$ per annum and its duration, amount and reliability increases with increase in altitude (KNBS, 2013)

Study Site : Marsabit County
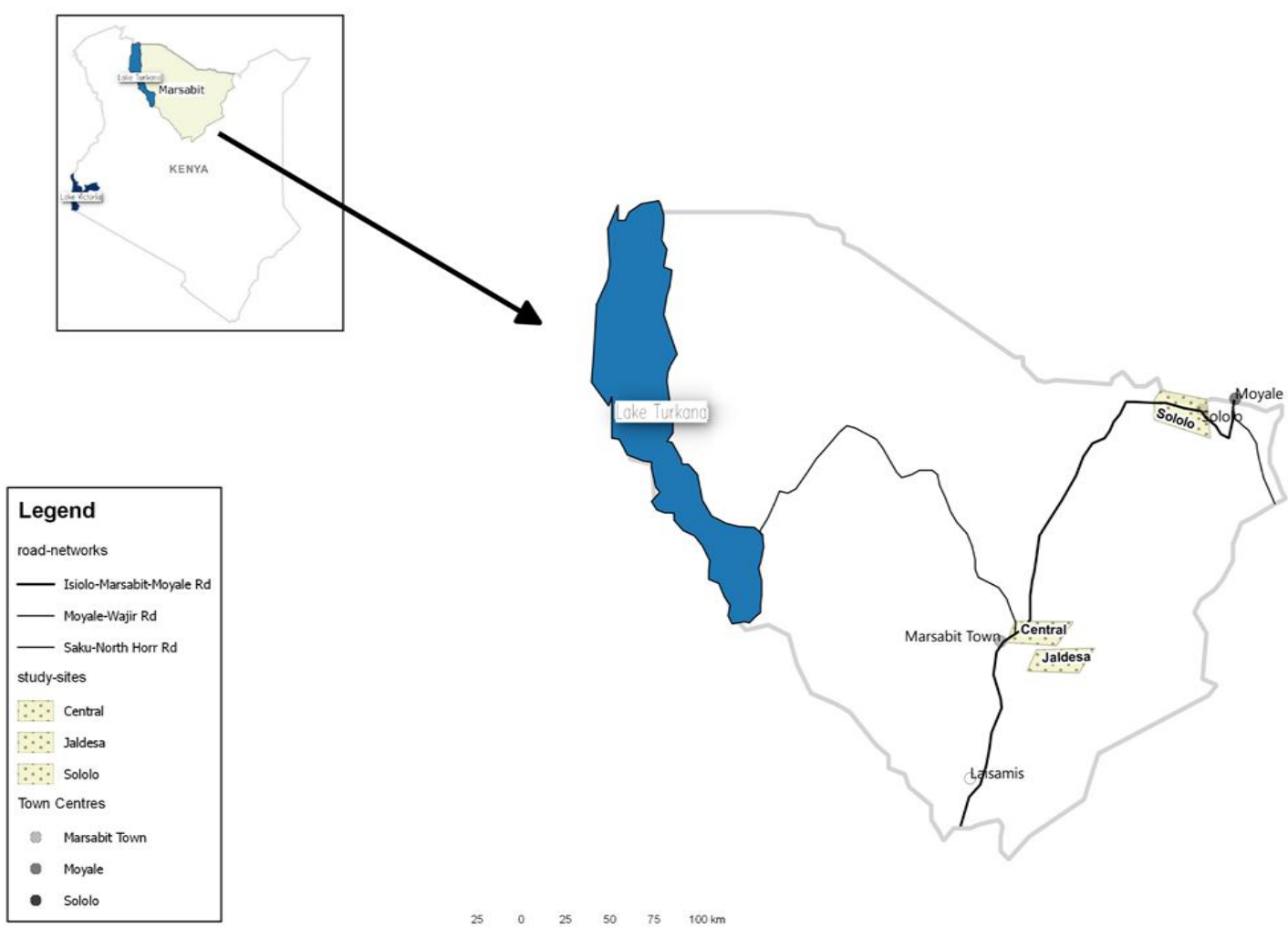

Figure 1. Location of Marsabit County showing study sites - Sololo, Central and Jaldesa region

\subsection{Research Design}

This research was carried out in Marsabit County Kenya, with group of women who lived in the villages within study sites. The research ethics were addressed by briefing the respondents about the purpose of the study and the processes involved and were assured of confidentiality. Verbal consent was then obtained from respondents to conduct the interviews.

The groups were diverse, with people interviewed differing from each other in a number of ways like in terms of gender, age, marital status and composition of household. To build relationships through the research process focus was made on particular region and people to get in-depth information on traditional meat knowledge by employing integrated approaches of key informant interviews, narrative interviews and participant observation. 
Initially, key informants and narrative interviews were used to get detailed data from the knowledgeable women who have been recommended by the key contacts and elders in the village. The in-depth interviews covered topics of what, how, when and why the traditional meat was processed and preserved. The respondent had time and space to give detailed information as she recalled and gave her experience on the traditional knowledge. There were no interruptions and respondents were confident and gave passionate information and felt appreciated.

Secondly, participant observation was conducted with the women groups to get data as the action unfolded. The women prepared the products giving insights into preparation, processing and preservation of meat products as they demonstrated.

The participants spoke the same language and the interview was conducted in Borana language as the researcher was also a native speaker of the language.

\subsection{Methods}

\subsubsection{Narrative Interview}

The narrative interview offered individual respondent to give an account of experiences in traditional meat processing as a form of custodian of that knowledge and skill because several narrators reflected on the past as a setting to contextualize their meaning.

At the beginning of the study, five knowledgeable women (three from Marsabit and two from Sololo) were identified with the help of local elders who were contact persons. After the interview, the women were asked to identify more knowledgeable women in their neighborhood. In total fifteen more were identified, bringing the total of interviewed women to twenty.

Participants were asked a series of open-ended questions about traditional meat processing and all activities involved recalling from their experiences. The respondent was given time to answer as they recalled and went back in time to tell their personal experiences and observations. Narration also allowed for probing and clarification where respondents told more on the topic. Interviews generally lasted between 40 minutes to one and half hours.

During the interview process, creating a relaxed atmosphere to communicate with the narrator was found to be important. To achieve the relaxed setting, ample time was created to initiate a small talk on general conditions of weather, livestock and happenings in the area, reducing any anxiety or feelings of uneasiness

\subsubsection{Key Informant Interview}

For key informant interview, purposive and snowball sampling was used to identify informants who in turn led to more knowledgeable women on traditional meat preservation technique. The following questions were used to guide the discussions: "Please explain what you do with the carcass after slaughter; what traditional meat products are made from the meat, please identify by these products by names in addition to how meat was prepared, preserved and consumed. In total, five key informants were conducted, and their responses recorded.

The aim of participatory observation was to observe and record women groups as they demonstrated the activities of making the recipes and processing of traditional meat products. Abarca, (2016), noted that the physical manipulation of a knife on a cutting board or dough rolled out on marble was a learned skill, and the memory of learning that skill was recalled in the process of performing these actions.

Participant's observation, was done with the same respondents of narrative and key informant interview who provided key contacts and recommendation on clusters of women groups.

From the three research sites, five women groups were identified to participate in practical demonstrations of processing the traditional meat products. The groups consisted of rural based women groups and peri-urban women groups. The sites for participant's observations were mostly at shared premises and in some cases at members home. All the participant observation took between two to three days.

Sound recording and video recordings were done to gather information on activities of traditional meat processing. For example, what quality they want to see, why the criteria mattered and selecting of criteria to be tested were recorded. Traditional meat product recipes and ingredients were documented through video recordings to come up with checklist for traditional meat products among women groups in each location.

To document recipes and ingredient of meat products five clusters of specialized women groups in each location were engaged in practical demonstration on how to prepare various traditional meat products. Meat was either sourced from butchery or a goat was purchased and slaughtered for the exercise. 
For participant observation in Obbu, we managed only to slaughter a goat for demonstration because the butchery did not stock beef. In central Marsabit, the women who showed interest in making products were the ones who were recommended as knowledgeable and older. This group is a peri-urban group and sourced meat from butchery. It was this group who made fonntummaa rare product. Jaldessa group, in the rural setting of Saku Sub-county, were mixed with both young and elderly. They also slaughtered a goat to make koche from goat meat due to distance from the urban center. This group being more rural and gave detailed knowledge on traditional meat practices. The younger women 20-35 years from this area seemed knowledgeable and gave valuable knowledge on meat practices

Table 1. Participants observation of traditional meat preparation exercise

\begin{tabular}{llllll}
\hline Study regions & Groups & Number of participants & Venue & Source of meat & Products made \\
\hline $\begin{array}{l}\text { Jaldesa } \\
\text { Central }\end{array}$ & Waldagena & 18 & Group's place & $\begin{array}{l}\text { Goat slaughtered } \\
\text { Beef steak and goat meat } \\
\text { purchased from butchery }\end{array}$ & $\begin{array}{l}\text { Koche } \\
\text { Koche } \\
\text { Fontuma } \\
\text { Gochegarbu }\end{array}$ \\
& & 10 & & & $\begin{array}{l}\text { Goups place } \\
\text { Central }\end{array}$ \\
& Mata arba & 7 & Members house & $\begin{array}{l}\text { Beef/steak purchased } \\
\text { from butchery }\end{array}$ & $\begin{array}{l}\text { Koche } \\
\text { Sololo }\end{array}$ \\
Sololo & Ramolle & 6 & & Members house \\
Goat slaughtered & Koche \\
& Borolle & 4 & Members house & Goat slaughtered & Koche \\
\hline
\end{tabular}

Observing and recording practical demonstrations of meat preparation, processing and preservation techniques were done for three traditional meat products of Koche, FonnTumma and kochegarbu. Active interaction was encouraged to categorize the traditional meat products according to types, methods, use of the products and occasion of use. Observation was made as the women engaged in the meat preparation and product handling activities. Video recording was done to enable analysis of the procedure. In addition, notes were taken and the activities were recorded. Informal talks and interactions took place as more documentation was done while actions unfolded and researcher sought further clarification on activities on what the participants assumed as obvious but which was very important form of tacit knowledge involved.

\subsection{Data Analysis}

The interviews were recorded on voice recorder, note book and transcribed verbatim. Once the interviews had been transcribed, the material was entered into the qualitative data analysis software RQDA and coded. The interviews were read to develop coding frame corresponding to issues. The code frame was categorized according to activities; knowledge, processing, products and preservation. When quoting text into the paper, the key word or theme was searched in the saved interviews to confirm the commonality and cited.

For participant observation, the following were documented: - name of traditional meat products, preparation methods, recipes and ingredients, criteria used in all stages and processes and why they did and what they did. Tacit knowledge observed were also recorded. In addition, traditional preservations methods applied by women were noted.

\section{Results}

\subsection{Borana Women's Traditional Meat Knowledge and Products}

When animal was slaughtered, the carcass was separated from other products such as liver, heart, kidney, pancreas, bones, fat, horns, hides and tails. The carcasses were cut into parts. The first part to be consumed was the soft organs referred to as daddam partly to avoid spoilage and acted as appetizer. The rest of the carcass was separated into meat used for short term and long term. Meat from hind legs was stripped and dried to make products like guba,koche and kataweel, and are thus earmarked for long term use.

Out of the fourteen meat products that were documented in the interviews, the women in almost all the groups had knowledge of preparing only four meat products. These were koche, guba, fonntuma and daddam. These products used to be consumed in large quantities at one serving, but this has changed since the introductions of cereals and pulses. We documented several artisanal meat products and the process of preparation from the interviews as shown in Table 2 below. 
Table 2. Borana artisanal meat products

\begin{tabular}{|c|c|c|c|c|c|}
\hline $\begin{array}{l}\text { Product } \\
\text { (Boran) }\end{array}$ & Description & $\begin{array}{l}\text { Source and parts } \\
\text { used }\end{array}$ & Method of preparation & Storage & $\begin{array}{l}\text { storage } \\
\text { time }\end{array}$ \\
\hline Koche & Deep fried red meat & $\begin{array}{l}\text { Beef/goat } \\
\text { Sirloin steak }\end{array}$ & $\begin{array}{l}\text { Cutting dried strip meat into } \\
\text { smaller pieces and deep fried }\end{array}$ & Stored in fat & 2 months \\
\hline Guba & $\begin{array}{l}\text { Deep fried red and } \\
\text { fatty meat }\end{array}$ & $\begin{array}{l}\text { Beef/goat } \\
\text { Steak and fatty } \\
\text { part }\end{array}$ & $\begin{array}{l}\text { Cutting dried striped meat into } \\
\text { smaller pieces and deep fried }\end{array}$ & Stored in fat & 2 months \\
\hline Fonntumma & $\begin{array}{l}\text { Deep fried ground } \\
\text { meat }\end{array}$ & $\begin{array}{l}\text { Beef/goat } \\
\text { Sirloin steak }\end{array}$ & $\begin{array}{l}\text { Roasting dried striped meat } \\
\text { then pounded and deep fried }\end{array}$ & Stored in fat & 3 months \\
\hline Kataweel & Shallow fried meat & $\begin{array}{l}\text { Beef /goat } \\
\text { steak }\end{array}$ & $\begin{array}{l}\text { Cutting dried striped meat into } \\
\text { pieces and shallow fried }\end{array}$ & Stored in fat & 1 month \\
\hline Fonnqadabe & Dried strip & $\begin{array}{l}\text { Beef/goat } \\
\text { steak }\end{array}$ & $\begin{array}{l}\text { Roasting dried striped meat } \\
\text { then eaten with fat }\end{array}$ & $\begin{array}{l}\text { Raw strips } \\
\text { stored in } \\
\text { traditional } \\
\text { subb }\end{array}$ & 2 months \\
\hline choomm & Fat & $\begin{array}{l}\text { fatty tissues from } \\
\text { meat }\end{array}$ & $\begin{array}{l}\text { Extracting of fat from fatty } \\
\text { meat and bones by boiling }\end{array}$ & $\begin{array}{l}\text { Stored in traditional } \\
\text { container dhool }\end{array}$ & 3 months \\
\hline Guguble & Fat granules & $\begin{array}{l}\text { fatty parts of } \\
\text { stomach tissues }\end{array}$ & By-product from extracted fat & In pots & 2 weeks \\
\hline Lafeqoan & Bone & $\begin{array}{l}\text { Beef/goat } \\
\text { bones }\end{array}$ & $\begin{array}{l}\text { Boiling bones repeatedly for } \\
\text { soup and fat }\end{array}$ & $\begin{array}{l}\text { Arranged on bedlike } \\
\text { structure saqe }\end{array}$ & 1 month \\
\hline Digallo & Meat on bone & Beef /goat & Boiled or roasted stored meat & Stored in subb/saqe & 1 month \\
\hline Marumandira & Dried intestines & $\begin{array}{l}\text { Beef/goat } \\
\text { intestines }\end{array}$ & $\begin{array}{l}\text { Boiling and placing intestines } \\
\text { in sticks to dry }\end{array}$ & Dried over fire place & 2 months \\
\hline Kochegarbu & $\begin{array}{l}\text { Mix of fried meat } \\
\text { with fried barley }\end{array}$ & $\begin{array}{l}\text { Beef/goat steak } \\
\text { and barley }\end{array}$ & Frying meat and barley & Stored in fat & 2 months \\
\hline kochemandasi & $\begin{array}{l}\text { Fried meat mix with } \\
\text { wheat flour }\end{array}$ & $\begin{array}{l}\text { Beef /goat steak } \\
\text { and Mandasi }\end{array}$ & Frying meat and wheat flour & Stored in fat & 1 month \\
\hline Radhu & $\begin{array}{l}\text { Soft inner parts of } \\
\text { hides/skin }\end{array}$ & $\begin{array}{l}\text { Beef /goat hide } \\
\text { and skin }\end{array}$ & $\begin{array}{l}\text { Boiling the soft tissue of skins } \\
\text { for soup }\end{array}$ & $\begin{array}{l}\text { Placed in the sun for } \\
\text { drying }\end{array}$ & 2 months \\
\hline Daddam & $\begin{array}{l}\text { Soft tissues and } \\
\text { organs }\end{array}$ & Beef /goat & $\begin{array}{l}\text { Boiling or frying soft organs } \\
\text { for sharing }\end{array}$ & None & 2 days \\
\hline
\end{tabular}

Women displayed their skills and knowledge on meat products and added value in terms of preserving it for future use. They employed methods such as strip and drying to reduce water content. One interviewee from Sololo expounded as:

'All the meat is removed from the bones, but before that they cook dadam (appetizer) ribs, liver and small piece of steak are cut; then cooked and given to neighbors and all household members. The red meat is removed from the bones and strip, for example, when one household slaughters; the women from the homestead assist the mother of the house in striping the meat overnight. They tie two threefold of rope around the hut for suspending the meat to dry.'

And another interviewee added,

if one household slaughter a bull, women from neighbourhood will come together and strip, strip and then arrange on rope... you see, in the past, Borana had big huts--- they used rope made from skin to tie two fold on one side and two folds on the other side... four folds of rope on one side and four on the other--- then when it dries... they remove and cut, cut cut and cut the whole night afterward it is cooked in melted bassa," (ghee) as the song line goes (basitun bassit kadatun dhafit") the cook fries and beggars sweats---- have you heard that in cattle song? You see the whole night they dress in work cloth 'wadhare' and cut, cut meat, cut meat to preserve.

Cooked meat was later kept in smoked storage containers (Dhola or Dhibe or Subb) and used over long time as it had long shelf life. One interviewee affirmed this as follows;

"On the other hand, dhigalos is meat which is only dried. Dried and kept away in subb, it does not get spoil; no, it does not, because it's not wet... The rest of meat which is eaten fresh were boiled--- bones, some other parts which is not made to guba or dhigalo, all these parts are boiled and eaten overtime. The father of the house is 
given some bones with pieces of meat, children are given pieces of meat and they drink the soup all day long they don't get hungry... when this one finishes, the jaji in subb was used... this was also given to the father of the house and children. "

The traditional knowledge of meat processing is declining, restricting this knowledge only to the elderly women. Even among the women, there are few who are known locally for their expertise in making the local meat product. In terms of geographical distribution of research site, the respondents from Sololo gave detailed knowledge on the past experiences of traditional meat practices and most of them were elderly.

For example, in Sololo, eighty-year-old respondent highlighted her knowledge through sayings, songs and proverbs, narrating practices she witnessed only during her youth.

"You see I cannot tell you what people do now, I do not know because at my age I belong to the old age so I don't make any koche. Um umm but what I have seen people of now a day'... make small circular things from wheat flour and call it koche. For me I know koche of fonn fila and garbu. When I was young my family is famous for cattle... you heard of "borr abbiyu lake" that was what was said do you know? Have you heard? (Borr abbiyu lakeh jaldessi saku dake, dheth bekhu daqe, onn bekhu daqe bor abbiyu lake') you heard. right... it's a line in cattle song. You see... those cattle were ours... and koche was plenty those times I am daughter of abbiyu lakke. the renowned cattle owner"

\subsection{Preservations Techniques and Handling of Traditional Meat}

Borana had several preservation techniques for storing meat for longer periods, drying of meat was observed as very important step in shelf stability of meat. Meat meant for longer stay is usually cut thin like a rope and suspended on the rope for aeration. Strip was the common technique when making traditional meat products. The participants were unanimous that strip meat have advantages like easier air circulation which enhance drying, ease of arranging on rope and also ease of cutting after drying. The drying was moderated as much as possible to avoid quality compromise. Respondents explained that too much drying leads to hardening of product while less drying leads to rotting. Sometimes sun drying is also practised especially by those at satellite camps for quick drying.

Use of heat in preserving is also applied. Meat is cooked by smoking, roasting or deep frying. Meat which is dried and preserved are usually smoked by fire place. The meat parts which are normally smoked are mogolle, Iree and rajeji (the lower hind legs, forelegs and pancreas), an action done to impart the sweet flavour and taste. Roasting of meat meant for pounding is done by putting the meat strip in between sticks and roasted over red charcoal. This is also done to impart flavour.

Another heat technique was deep frying of meat where the meat was heated for a short period of ten to twenty minutes. The use of additives in the meat also enhanced its quality. The addition of salt, sugar and cardamom not only improved flavor but also help in extending the shelf life of the products by playing role in reducing the water activity and furthermore these products are known to have antimicrobial properties which reduces the levels of spoilage. A respondent from Central region opined thus.

“.... you know, this food, we have added new things, that enhances aroma when this jug is open ... you can smell the good aroma so we do not use urgo, we use elki,(cardamom) I remove the top part ground like sugar and add at the point of removing the meat from fire. When I add elki at the beginning of cooking the entire aroma remain in the pot...... not with meat. You add at the finish."

The storage containers were smoked well with special kind of sticks which gave good aroma and also enhanced the shelf life of the products. Smoking was done on traditional storage containers to impart flavor and to keep the product for long in storage. Subsequently the meat products were stored in oil. The oil was full enough to cover the product which created state of protection in reducing spoilage and keep the long. 
Table 3. Meat preservation techniques among Borana Pastoralist in Marsabit County, Northern Kenya

\begin{tabular}{|c|c|c|c|}
\hline $\begin{array}{l}\text { Preservation } \\
\text { technique }\end{array}$ & Objectives & Activities & Prevalence of use \\
\hline Drying & $\begin{array}{l}\text { To reduce the water } \\
\text { content }\end{array}$ & $\begin{array}{l}\text { Striping of meat and drying by } \\
\text { suspending on ropes for } \\
\text { aeration. }\end{array}$ & Common about $90 \%$ of respondents still practice \\
\hline $\begin{array}{l}\text { Preservation by use } \\
\text { of heat }\end{array}$ & $\begin{array}{l}\text { To reduce the water } \\
\text { further and cooking the } \\
\text { meat }\end{array}$ & $\begin{array}{l}\text { Roasting, deep frying and } \\
\text { cooking of meat }\end{array}$ & Common about $90 \%$ of respondents still practice \\
\hline Storing in fat & $\begin{array}{l}\text { To preserve meat by } \\
\text { reducing air entry }\end{array}$ & $\begin{array}{l}\text { keeping of meat products by } \\
\text { immersing in fat }\end{array}$ & $\begin{array}{l}\text { Not very common } 50 \% \text { of respondents say they } \\
\text { completely immersed the meat in fat }\end{array}$ \\
\hline $\begin{array}{l}\text { Additions of salt, } \\
\text { spices and sugar }\end{array}$ & $\begin{array}{l}\text { For flavor } \\
\text { preservation }\end{array}$ & $\begin{array}{l}\text { adding small parts of salt, } \\
\text { cardamom and sugar }\end{array}$ & Common $90 \%$ of respondents use additives \\
\hline $\begin{array}{l}\text { Smoking of storage } \\
\text { containers }\end{array}$ & $\begin{array}{l}\text { To improve the flavour } \\
\text { and preserve the meat }\end{array}$ & $\begin{array}{l}\text { keeping products in smoked } \\
\text { containers }\end{array}$ & $\begin{array}{l}\text { Occasional, } 20 \% \text { of elderly women use smoked } \\
\text { traditional containers. The rest use aluminum jug } \\
\text { for storage }\end{array}$ \\
\hline
\end{tabular}

\subsection{Product Preparations and the Observed Tacit Knowledge of Borana Women in Making Traditional Meat Products}

Before the actual processing and preservation phases, women systematically gathered tools and implements which helped them carry out the activities. These included cutting knives, cooking pots, ropes for suspension, bowls, spoons, firewood, fireplace, charcoal, wooden mortar and pestle. The meat preparation process flow chart is shown in figure 2.0 below.

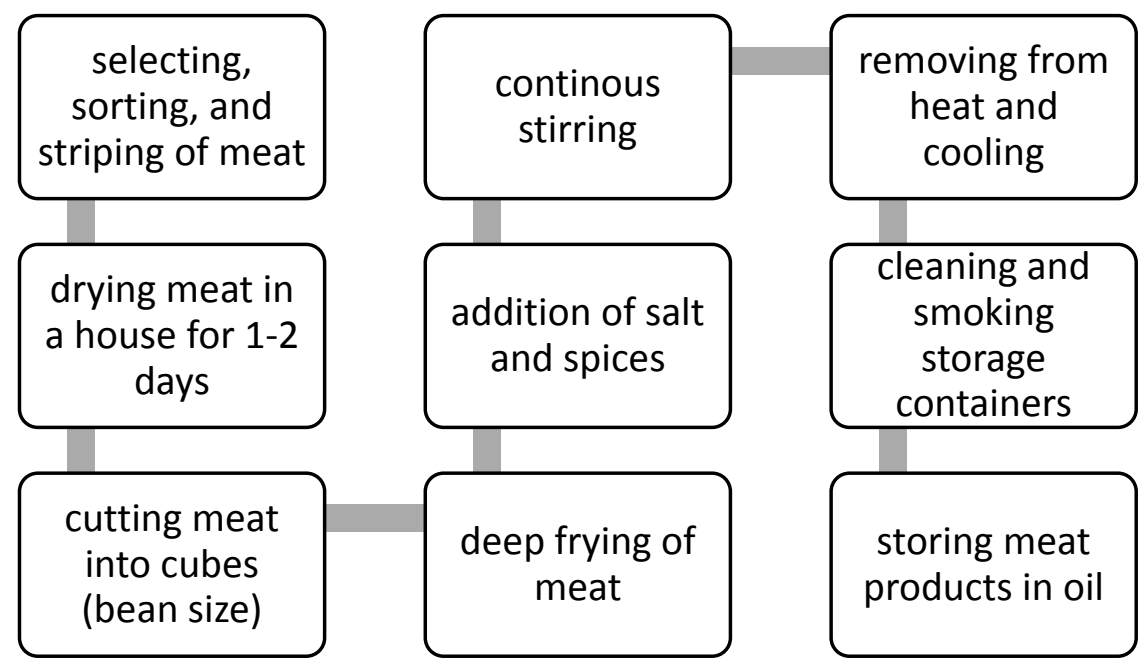

Figure 2. Traditional meat "koche" preparation flow chart

The part of meat selected to make traditional meat was important, where women automatically removed and sorted the meat out, as a first step in Figure 2.0. When buying from the butchery and if it was meant for koche the butcher was instructed to cut steaks (rump, thick flank and silverside or all) depending on desired size. When it was home slaughtered the hind leg, steaks are usually prized and reserved for making koche. The women explained that the part which makes the best products are the steaks of hind leg which has the red meat (as they called it Allalo). They further clarified that, it should have less fat and less ligaments. The ribs and back meat were described as parts which cannot produce good koche due to its hard texture. Sorting was done to remove fatty tissues and ligaments which the women said that it made the products hard and also led to early spoilage. Respondent summarized these by commonly used proverb that 'tandach thiiqaat fonn ajesa'meaning small fatty node if not removed can lead to rotting of whole meat part. 
When making the strip the sitting position was kind of natural as women enjoyed sitting on traditional stools and bent to cut meat into bean size pieces by holding the knife in between their toes, as shown in the second photo of Figure 3.0 below. This they explained that it helped them to do the work quickly and also when alone one does not need a helping hand. The only shortcoming of this technique was as they explained that "it's a bit tiring, causes backache when done for long". Another technique was where two people were involved with one holding the meat and while the other did the strip. The only problem with this, as they explained, was that the holder sometimes holds the strip loosely making the cutting slow and cumbersome.

After strip process, hand-made rope was sought, cleaned and tied. For arranging strip, the women had a particular way of arranging the strip. They would hold the strip making some kind of inverted $\mathrm{W}$. This was said to make it easier for removal without making a knot on the rope and also helped in spacing. The exercise was done with such an ease and it was very natural. After drying, the meat was cut into bean size or tiny cubes. The women knew that different sizes give out different results when cooked, especially as different sizes leads to undercook for bigger and burning for tiny sizes. They therefore inherently maintained uniform cut sizes.

Drying of traditional meat product is considered critical stage of processing, as shown in process flow chart in Figure 2.0. Drying are of two types, where one is moderate drying or kafaf, done within $24 \mathrm{hrs}$. This is where the meat is dried in the house at room temperature to maintain good texture of the product. The individual preparing would look and touch the meat and conclude that it's at right stage of having been dried. Meat products made from such method are koche, guba and kataweel.

This is a quote from respondent from Marsabit central

"and the steak is being strip then suspended to remove water, dry off wetness and when it dries it has to be moderate (kafaf) the active women alaqa now, start processing before it becomes smelly. The reason why strip is done is because the meat has water when fresh"

The other drying method is complete drying or gogosa. Here, the strip was cut thinly and dried for several days, at least 55 hours. This was done to store the raw meat in Suub or Dhool for future use. This complete drying technique is also a procedure for fonntuma.

Drying is very important step in traditional meat processing making. The women explained in participant observation that if koche is not dried it does not cook to golden brown color. If the meat does not attain the golden-brown color it remains grayish, then it does not last for long and the unique aroma of koche will not be felt.

Further drying took place when deep frying was applied. The women explained that the steam which comes out removes more moisture. Frying was done until the meat released brownish bubbles which indicated that the product was ready. In case of roasting, the meat was roasted till its golden brown while burning was avoided. The pleasant aroma from meat also signified the readiness of meat. The women applied their skill in preparation in addition to constant observations made through unspoken actions. They used their senses to measure the quality of prepared and cooked meat. Organoleptic properties of taste, aroma, appeal and texture were used to measure the progress at different stages of preparation.

For fontuma, pounding was done to make meat have filaments like fish. This reduced the size completely and increased surface area for absorbing more oil. Prior to pounding the thin dried strip meat were roasted over red charcoal. The roasting helped in grounding as it also imparted flavor. Depending on the size of the pounded meat, the process can take between one to two hours. The process of lifting pestles and crushing meat in a mortar continually was labor intensive and it needed energy. During participant observation older women requested younger ones to do the pounding on their behalf.

While roasting the meat, women used dry stick made into 'scissor or plier like' for holding meat strip as shown in the third photo of Figure 3.0. Three to four meat strips were arranged in between the sticks and suspend over the red charcoal with continuous turning. The arrangement was then turned frequently from time to time making sure that it does not touch the live charcoal to avoid burning the meat. This was done skillfully and systematically by the women.

During the deep frying, frequent stirring was made. This was done to make sure of uniform spreading of heat and release of more vapor from the product. A long stirring spoon was normally preferred for this exercise to avoid hot escaping vapors while turning the pieces properly.

Storage process was regarded as one of the most important preparation aspect to yield better meat product in terms of shelf life and quality. A traditional storage container called Ejito made from wood was used. The smoking sticks, (qalqach and bisiqaaa) were inserted inside the Ejiito till some steam was produced. Smoking 
continued until the steam dried and was closed to cool for a while. Closing helped in imparting the aroma inside. Wetness and water inside the Ejiito was avoided completely. This is represented in the last photo in Figure 3.0

Cooling was important in traditional meat preparation. The respondents said that after the heating process, the products were left to cool. They encourage that no covering of the heated product be done to avoid steam on the cover from dripping back to the content. This is also done to prevent spoilage. One interviewee narrated the importance of cooling thus.

"After cooking I remove from the fire and place it down with the oil. After it is cooled is when you cover--because if covered while it's hot, the steam from cover will fall back into it. This steam becomes water later, and if this steam gets into meat, the meat will get spoilt.so it's good to keep uncovered while it's cooling".

Stripping

Cutting

Roasting

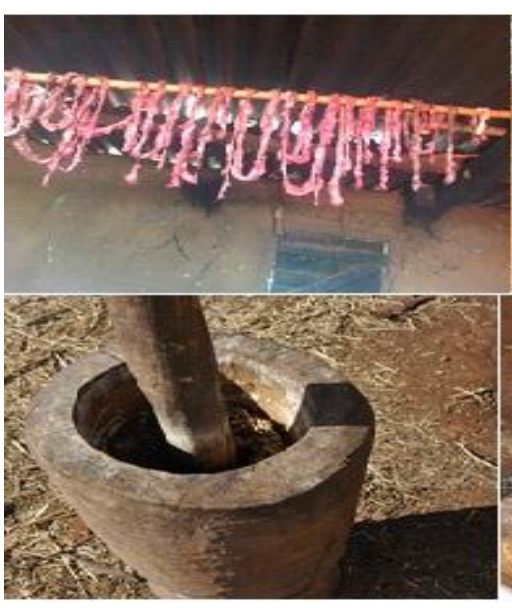

Pounding

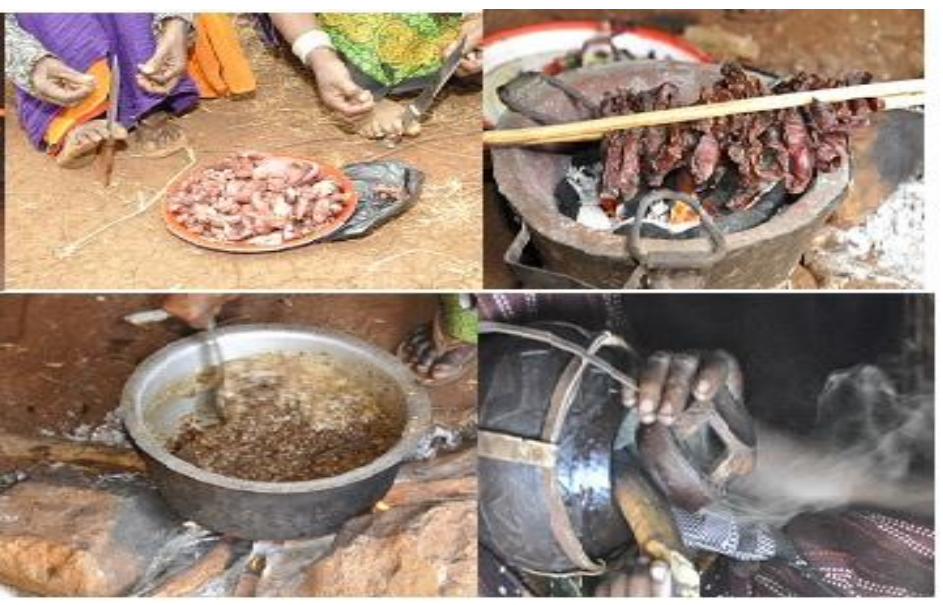

Frying
Smoking storage Container

Figure 3. Photos of traditional meat processing and preservation activities.

\section{Discussions}

Participants displayed both general and deeper product specific knowledge. Especially the elderly women displayed good understanding of the various meat preparation techniques, depicting how this was ingrained in their culture during their youthful life. They expressed their societal reverence for cattle in songs, wise saying and proverbs. This however affirmed the fear that this knowledge is dwindling as the aged population is getting decimated and less skill transfer is taking place. Nevertheless, more women in the semi urban and rural divide, than in the peri-urban settlements have shown interest to pass the knowledge to their daughters.

The respondent women have rich and deep knowledge of traditional meat products, these skills are learnt overtime and with experiences. From the responses there was a reason behind all the technique they applied, for instance they understood that the foundation of spoilage and contamination was water. Therefore, from the initial steps of slaughtering they regarded drying as one of the important step in making meat product that is shelf stable.

From the interviews, the women showed that they are knowledgeable on traditional meat processing only that the elderly women recalled deeper detailed knowledge than the younger counterparts. In Sololo, which is more rural and borders Southern Ethiopia, the Borana still practised their culture and meat preparation techniques are still richly remembered. This is owed to less exposure to other modern food ways and less distractions to cultural ways.

Most respondent gave general knowledge on meat processing despite their age. However, women who are fifty years and above gave aspect of traditional meat knowledge with interest and passion and recalled their experiences of why, how, who and what of artisanal meat knowledge and processing.

Currently, there are emergence of butchery and slaughter houses in the region where people buy meat unlike in the past where households slaughtered even for home use as the source of food supply. Nevertheless, the few who sourced from butchery still employ selection and preference for parts, where women purchase the steak of hind leg for these purposes of making "Koche". 
In Central division of Marsabit County, most people sourced their beef supply from butcheries, such that when one needed to make the traditional products, they have choices of what parts for cuts and where to source from. Most respondent agreed that beef was preferred for koche than goat meat because of the longer shelf life and also the size. In Sololo and Jaldessa, most villages did not have butchery, hence people still slaughtered small stock (goats) for home use or cattle when it was a big occasion. The few butcheries in the Sololo township only stocked goat meat. In all the three places, it had emerged that due to lifestyle changes, the slaughter of bulls had been on the decline except for ceremonies and thanksgiving, which were also fewer in occurrence. This gives credence to the notion of dwindling traditional meat handling knowledge amongst the Borana community of Northern Kenya.

For the participant observation, women groups were selected to demonstrate how the traditional meat wa s processed. This was done because most groups selected were already engaged in similar activities and the selection enhanced their abilities to do something they already knew. They passionately shared their experiences, expertise and also learnt from each other during their get-to-gather sessions.

Traditionally, Borana are organized along kinship lines into tribes and clans. This organization was used in socialization and networking and helped in sharing of responsibilities. Women would invite their friends and neighbors during occasion of slaughtering to help in the chores. However, with advent of modernization, there are emergence of women and self-help groups who come together for purposes, such as pulling efforts together to achieve tasks satisfactorily in shorter time. Hence working with these existing and active groups offered the importance of getting insider information through participatory methods which also gave the group opportunities to showcase their knowledge. As Kuhnlein (1996) postulated since indigenous people are tenants of traditional food system knowledge, inter institutional initiatives will be more likely to contribute to the development of these resources if indigenous people are encouraged to participate.

Among the groups who demonstrated the processing of traditional meat, there were concepts which were similar to each group. Selecting of parts, the steak, striping and drying were done in similar ways for four groups out of five. The other group differed in the process at point which oil was added. While rest of the groups cooked the meat first and added the oil later; this other group boiled the oil and added the meat, explaining that when meat is put into boiling oil the rate of moisture removal is higher.

From what the women groups demonstrated the knowledge of meat processing do exist, except that those who took part in demonstrating are older women. Therefore, there is opportunity for groups to make it one of their income generating activities targeting the locals who value the uniqueness and social value attached to the products, nonetheless other consumers will also be attracted to home made products which define the locality.

The women knew that meat is a perishable product and needed to be preserved in order to extend shelf life hence the need to reduce water/ moisture content. The women made use of drying meat moderately at room temperature by striping the meat to increase surface area for better evaporation and knew at what stage the extent of dryness was to be done. This demonstrated inherent tacit knowledge that the women had.

They also deep fried at high temperature of $200^{\circ} \mathrm{C}$ after cutting into small cubes to remove more water till the meat turned to dark red by removing dark brown bubbles of oil which acted as a guide that most moisture have been removed. The meat was cooled overnight without cover to avoid collection of steam which eventually drips back to meat. Covering of meat was avoided for enhanced keeping quality. The cooled meat was then stored in smoked traditional container dipped in oil. This art had a preservative effect as the oil protected the meat from spoilage and helped preserve the quality.

\section{Conclusion}

The preparation of traditional meat products is an artful activity, one that requires skill and knowledge. Appreciation of the quality of these products are partly rooted in tacit knowledge of the expert women, who by their advanced age are getting fewer and will lead to gap of this knowledge in the years to come. This was evidenced by the fact that out of the fourteen documented meat products, only four products are currently being practiced. Also, with fewer ceremonial events that can occasion slaughter of cattle for meat, few opportunities arise for passing knowledge through experience. Therefore, conscious efforts need to be initiated to address the generational gap and create awareness about this knowledge amongst the younger generation so that traditional food ways are preserved and/or integrated with modern food handling techniques.

The knowledge on processing exhibited by the women established that by improving some stages of processing through value addition traditional meat product could be suitable and appealing not only for home consumption but market-oriented income generating activities. For example, striping of meat and drying processes takes days 
and is labour-intensive, hence need to mechanize the process for commercialization. It is therefore important for policy makers and development agencies to equip food handling processes to expand the knowledge and skills for market adoption.

Nevertheless, less reliance on beef and beef products as occasioned by introduction of cereals and pulses, have diverted pastoralists dependence on meat products. Therefore, planned policy directives are an imperative to saving these traditional knowledges for future generation.

\section{Acknowledgement}

The Author acknowledges and thank RELOAD project for funding the study

\section{Reference}

Abarca, M., \& Colby, J. (2016). Food memories seasoning the narratives of our lives. Food and Foodways, 24, 1-8. https://doi.org/10.1080/07409710.2016.1150101

Agrawal, A. (1998) Dismantling the divide between indigenous and scientific knowledge. Development and Change, 26(3), 413-439. https://doi.org/10.1111/j.1467-7660.1995.tb00560.x

Bessière, J. (1998). Local development and heritage: traditional food and cuisine as tourist attractions in rural areas. Sociologia Ruralis, 38(1), 21-34. https://doi.org/10.1111/1467-9523.00061

Bora, L., \& Bam, J. (2014) Traditional milk, meat processing and preservation techniques of the Yak Pastoralists of Arunachal Pradesh. IJTK, 13(1). http://hdl.handle.net/123456789/26019

Cajete, Gregory. (2000). Native science: Natural laws of interdependence. Santa Fe, NM: Clear Light Publishers

Chikati, D. (2014). Contribution of indigenous education in proper nutrition a case of Bukusu community of Kenya. International journals of innovative research \& studies.

Dabasso, B. H., Taddese, Z., \& Hoag, D. Pastoralism (2014). Carbon stocks in semi-arid pastoral ecosystems of northern Kenya. Pastoralism: Research, Policy and Practice, 4(5). https://doi.org/10.1186/2041-7136-4-5

Feagan, R. (2007). The place of food: mapping out the "local" in local food systems. Progress in Human Geography, 31(1), 23-42. https://doi.org/10.1177/0309132507073527

Fnifst, O. C. A. P. (2008). The Role of Traditional Food Processing Technologies In National Development: the West African Experience. Retrieved from https://www.researchgate.net/publication/237218596

Fonte, M. (2008). Knowledge, Food and Place. A Way of Producing, a Way of Knowing. SociologiaRuralis, 48, 200-222. https://doi.org/10.1111/j.1467-9523.2008.00462.x

Guyot, M., \& Dickson, C. (2006). Local observations of climate change and impacts on traditional food security in two northern Aboriginal communities. International Journal of Circumpolar Health, 65, 403-415. https://doi.org/10.3402/ijch.v65i5.18135

Kenya Population and housing Census (2009). Kenya National Bureau of Statistics (KNBS)

Kuhnlein, H. V., \& Receveur, O. (1996). Dietary change and traditional food systems of indigenous peoples. Annual review of nutrition, 16, 417-442. https://doi.org/10.1146/annurev.nu.16.070196.002221

Liao, C. (2014). Case Study: Borana, Ethiopia. http://www.atkinson.cornell.edu/Assets/ACSF/docs/collaborations/oxfam/Borana

Ministry of health Kenya (2013). Household Health Expenditure Survey and Kenya National Bureau of statistic.

Nam, K.-C., Jo, C., \& Lee, M. (2010). Meat products and consumption culture in the East. Meat Science, 86(1), 95-102. https://doi.org/10.1016/j.meatsci.2010.04.026

Nonaka, Ikujiro. (2006). Creating sustainable competitive advantage through knowledge-based management. Retrieved from http://www.opdc.go.th/uploads/files/nonaka.pdf

Ohmagari, K., \& Berkes, F. (1997). Transmission of indigenous knowledge and bush skills among the Western James Bay Cree women of subarctic Canada. Human Ecology, 25(2), 197-222. https://doi.org/10.1023/A:1021922105740

Oniang'o, R., Allotey, J., \& Malaba, S. J. (2004). Contribution of indigenous knowledge and practices in food technology to the attainment of food security in Africa. Journal of Food Science, 69(3), CRH87-CRH91. https://doi.org/10.1111/j.1365-2621.2004.tb13346.x

Roth, K. (2001). Material culture and intercultural communication. International Journal of Intercultural 
Relations, 25(5), 563-580. https://doi.org/10.1016/S0147-1767(01)00023-2

Rai Arun \& Palni Uma (2009). Traditional knowledge of the Himalayan people on production of indigenous meat product. IJTK, 08(1), 104-109. http://hdl.handle.net/123456789/2980

Vallianatos, H. (n.d.). Joy Adapon. Culinary Art and Anthropology. Oxford: Berg, 2008. 160 Pages. https://www.rochester.edu/in_visible_culture/Issue_14/reviews/adapon.html

\section{Copyrights}

Copyright for this article is retained by the author(s), with first publication rights granted to the journal.

This is an open-access article distributed under the terms and conditions of the Creative Commons Attribution license (http://creativecommons.org/licenses/by/4.0/). 